\title{
Cardiovascular responses of peripheral artery disease patients during resistance exercise
}

\author{
Respostas cardiovasculares durante o exercício de força em pacientes \\ com doença arterial periférica
}

Ana Patrícia Ferreira Gomes', Thaliane Mayara Pessôa dos Prazeres', Marilia de Almeida Correia', Fábio da Silva Santana', Breno Quintella Farah¹, Raphael Mendes Ritti-Dias

\begin{abstract}
Background: Resistance training has been used for the treatment of patients with peripheral artery disease (PAD). However, cardiovascular responses during this type of exercise have not been fully elucidated in these patients. Objectives: To analyze the cardiovascular responses during resistance exercise and to verify whether there are any correlations between these responses and disease severity or blood pressure levels in patients with PAD. Methods: Seventeen PAD patients performed one set of 10 repetitions of knee extension exercise with an intensity of $50 \%$ of one repetition maximum. The responses of systolic blood pressure (SBP), diastolic blood pressure (DBP) and heart rate $(H R)$ were continuously monitored using the finger photoplethysmography technique. The rate-pressure product (RPP) was obtained by multiplication of SBP and HR. Results: During the resistance exercises there were significant increases in SBP (126 \pm 14 vs. $184 \pm 20 \mathrm{mmHg}, p<0.001)$, DBP (68 \pm 8 vs. $104 \pm 14 \mathrm{mmHg}, p<0.001), H R$ (76 \pm 18 vs. $104 \pm 30$ bpm, $p<0.001)$ and RPP $(9523 \pm 2115$ vs. $19103 \pm 6098$ mmHg x bpm, $p<0.001)$. A negative correlation was observed between relative change $(\triangle)$ in SBP and SBP at rest $(r=-0.549, p=0.022)$. On the other hand, there was no relationship between $\triangle$ SBP and the ankle-brachial index $(r=0.076, p=0.771)$. Conclusion: Increases in cardiovascular variables were observed during resistance exercise in PAD patients. The highest increases occurred in patients with lower SBP levels at resting.
\end{abstract}

Keywords: peripheral artery disease; intermittent claudication; exercise; blood pressure; heart rate

\begin{abstract}
Resumo
Contexto: $O$ treinamento de força vem sendo utilizado para o tratamento de pacientes com doença arterial periférica (DAP). No entanto, as respostas cardiovasculares durante a realização desse tipo de exercício ainda não são claras nesses pacientes. Objetivos: Analisar as respostas cardiovasculares durante a realização do exercício de força e verificar se existe alguma correlação entre essas respostas e a severidade da doença e o nível de pressão arterial em pacientes com DAP. Métodos: Dezessete pacientes com DAP realizaram uma série de dez repetições com intensidade de 50\% de uma repetição máxima do exercício extensão do joelho. As respostas da pressão arterial sistólica (PAS) e diastólica (PAD), e da frequência cardíaca (FC) foram continuamente registradas pela técnica de fotopletismografia de dedo. O duplo produto (DP) foi obtido pela multiplicação da PAS pela FC. Resultados: Durante a realização do exercício de força, houve aumento significante dos seguintes parâmetros: PAS (126 \pm 14 vs. $184 \pm 20$ mmHg; p < 0,001); PAD (68 \pm 8 vs. $104 \pm 14$ mmHg; p < 0,001); FC (76 \pm 18 vs. $104 \pm 30$ bpm; $p<0,001)$, e DP (9523 \pm 2115 vs. $19103 \pm 6098$ bpm x mmHg; $p<0,001)$. Foi observada correlação negativa entre o delta $(\Delta)$ relativo da PAS com a PAS de repouso $(r=-0,549 ; p=0,022)$. Por outro lado, não foi observada relação entre o $\triangle$ relativo da PAS e o índice tornozelo braço $(r=0,076 ; p=0,771)$. Conclusão: Foram observados aumentos das variáveis cardiovasculares durante o exercício de força em pacientes com DAP. Os maiores aumentos ocorreram nos pacientes com menor nível de PAS em repouso.
\end{abstract}

Palavras-chave: doença arterial periférica; claudicação intermitente; exercício; pressão arterial; frequência cardíaca.

'Universidade de Pernambuco - UPE, Exercise Hemodynamics and Metabolism Research Group, Recife, PE, Brazil.

Financial support: Conselho Nacional de Desenvolvimento Científico e Tecnológico; Fundação de Amparo à Ciência e Tecnologia do Estado de Pernambuco; Coordenação de Aperfeiçoamento de Pessoal do Nível Superior.

Conflicts of interest: No conflicts of interest declared concerning the publication of this article

Submitted: October 25, 2013. Accepted: September 24, 2014.

The study was carried out at the Exercise Hemodynamics and Metabolism Laboratory, School of Physical Education, Universidade de Pernambuco, Recife (PE), Brazil. 


\section{INTRODUCTION}

Peripheral artery disease (PAD) describes the structural and functional dysfunctions that affect arteries that supply the peripheral regions of the body, primarily the lower limbs. ${ }^{1}$ In Brazil, the prevalence of PAD is approximately $10.5 \%$ in the population over 18 years of age. ${ }^{2}$ It is known that patients with PAD are at high risk of fatal and nonfatal cardiovascular events, ${ }^{3,4}$ due to coexistence with other diseases, such as: arterial hypertension, diabetes mellitus and cardiac and cerebrovascular diseases. ${ }^{5-7}$

Supervised physical exercise is recommended as a first line treatment for patients with PAD. ${ }^{8}$ More specifically, resistance training has been shown to increase functional capacity and quality of life in patients with $\mathrm{PAD},{ }^{9,10}$ and also provokes acute reductions in arterial blood pressure. ${ }^{11}$ It is therefore relevant to determine these patients' cardiovascular responses and the cardiovascular risk involved during this type of exercise.

It is already known that during resistance training there is an accentuated increase in arterial blood pressure in both healthy and hypertensive people, ${ }^{12,13}$ which could be considered a risk to the cardiovascular system. ${ }^{14,15}$ To date, just one study has investigated cardiovascular responses during resistance exercise in PAD patients. ${ }^{16}$ The results indicated that, in absolute terms, mean peak systolic arterial blood pressure during exercise was approximately $160 \mathrm{mmHg}$. However, since these measurements were taken while subjects were engaged in isokinetic resistance exercises, which is not the type of exercise that is performed in gyms (isoinertial exercise), the cardiovascular responses of patients with PAD during isoinertial resistance exercises remain unknown. Additionally, the influence of disease severity and the values of arterial blood pressure at rest on the magnitude of cardiovascular responses to resistance exercise have not been investigated yet. This information could help in identification of people whose cardiovascular responses to exercise are more extreme.

It should also be pointed out that the study that has been conducted employed the auscultatory method, which underestimates SBP during resistance exercise. It is recognized that the gold standard technique for measurement of arterial blood pressure during resistance exercise is the intra-arterial method, ${ }^{15}$ although this has the disadvantage of being an invasive technique. One noninvasive option that has been employed is the finger photoplethysmography technique, which has proven a valid method for analysis of changes to SBP in hypertense patients during resistance exercise. ${ }^{17}$ Thus, the objective of this study was therefore to analyze cardiovascular responses during resistance exercises in patients with $\mathrm{PAD}$, in addition to verifying the correlation between cardiovascular responses and disease severity and resting SBP.

\section{METHODS}

\section{Patients}

Seventeen patients with PAD and limitations including intermittent claudication were recruited at public hospitals and private clinics in the Metropolitan area of the city of Recife, Brazil. Inclusion criteria were as follows: a) age $\geq 45$ years; b) ankle-brachial index $(\mathrm{ABI}) \leq 0.90$ at rest; $\mathrm{c})$ absence of autonomic disorders if diabetic; and d) any impediments to engaging in resistance exercises.

All of the patients who volunteered to take part in the study signed free and informed consent forms. This study was approved by the institutional Ethics Committee under protocol number 134/09.

\section{Clinical assessment and identification of risk factors}

Patients were interviewed to collect information about the disease, their medical histories and their medications. Additionally, all volunteers were examined by a physician specialized in cardiology at the Pernambuco emergency cardiology center (PROCAPE - Pronto Socorro Cardiológico de Pernambuco), who assessed clinical condition, use of medication and the results of cardiological examinations conducted prior to the study.

\section{One repetition maximum test (1-RM)}

Patients underwent a 1-RM to test maximum lower limb strength. The test was started at the lowest intensity possible with the patient performing 10 repetitions. And an experienced evaluator then adjusted the load on the knee extension machine for the next attempt, on the basis of observation of the patient's performance on the first attempt. Each patient was allowed five attempts with five-minute recovery intervals between each attempt. ${ }^{18,19}$ The 1-RM value was defined as that load at which the patient was able to perform a single repetition of the knee extension exercise with full amplitude and correct movement. During each phase of the test, the patient was asked about the load and the number of repetitions accomplished, to provide additional 
information on which to base the choice of the next load. Patients were instructed to breathe adequately during exercise, thereby avoiding the Valsalva maneuver. If it was not possible to identify the 1-RM load in that session, another test day was scheduled after a minimum interval of one week.

\section{Experimental session}

A minimum of 72 hours after the 1-RM test, the experimental session was conducted and consisted of one set of 10 repetitions of the knee extension exercise with an intensity of 50\% of 1-RM. Patients were instructed to execute the exercise in a correct manner and with full amplitude. Patients were also instructed to avoid the Valsalva maneuver during the exercise. A submaximal exercise test was chosen on the basis of recommendations found in the literature. ${ }^{9,20}$

Patients' arterial blood pressure was monitored throughout the experimental session using the finger photoplethysmography method (FMS - Finapress Medical System, Arnhem, Netherlands).

\section{Photoplethysmographic analysis of arterial blood pressure}

Measurements of systolic blood pressure (SBP), diastolic blood pressure (DBP) and heart rate (HR) were taken using a Finometer ${ }^{\circledR}($ FMS - Finapress Medical System, Arnhem, Netherlands), employing the noninvasive photoplethysmographic technique for beat-by-beat monitoring of arterial blood pressure. ${ }^{21}$

The machine was calibrated before use and the measurements were taken before starting the exercise (pre-exercise) and continuously throughout the knee extension exercise. For the analysis, the pre-exercise measurement was calculated by taking the mean of the last five arterial blood pressure measurements taken at rest, whereas the highest values recorded during the exercise were used for SBP, DBP and HR. Once data had been collected, the rate-pressure product (RPP) was obtained by multiplying SBP by HR.

\section{Statistical analysis}

Normality and homogeneity of the variance in the data were analyzed using the Shapiro-Wilk and Levene tests respectively. The responses of cardiovascular variables were analyzed by applying the paired $t$ test to compare results pre-exercise and during the resistance exercise. Pearson's correlation coefficients were used to analyze the relationship between the relative deltas $(\Delta)$ of SBP and ABI and $\mathrm{SBP}$ values at rest.

All analyses were conducted using SPSS software, version 20.0. The level of significance adopted was $p$ $<0.05$ and results are shown as means and standard deviations.

\section{RESULTS}

Table 1 lists the characteristics of the patients enrolled on the study.

The majority of patients were female and had associated comorbidities, the most prevalent of which were arterial hypertension, followed by diabetes mellitus and dyslipidemia. Patients were taking medications for anti-hypertensive therapy and peripheral vasodilators.

Figure 1 illustrates the responses of arterial blood pressure levels during the resistance exercises.

Compared to pre-exercise values, significant increases were observed in SBP (pre-exercise $=126$ $\pm 14 \mathrm{mmHg}$ vs. peak $=184 \pm 20 \mathrm{mmHg} ; \Delta=+57 \pm$ $21 \mathrm{mmHg} ; \mathrm{p}<0.001$ ) and DBP (pre-exercise $=68$ $\pm 8 \mathrm{mmHg}$ vs. peak $=104 \pm 14 \mathrm{mmHg} ; \Delta=+37 \pm$ $15 \mathrm{mmHg} ; \mathrm{p}<0.001$ ). Five patients reached SBP values greater than $200 \mathrm{mmHg}$ and the maximum value observed for this variable was $230 \mathrm{mmHg}$, by one patient. The maximum DBP value observed was $148 \mathrm{mmHg}$ (Figure 1).

Table 1. General characteristics of patients with peripheral arterial disease $(n=17)$.

\begin{tabular}{lc}
\hline \multicolumn{1}{c}{ Variables } & Values \\
\hline Women/men $(\mathrm{n})$ & $12 / 5$ \\
Age (years) & $66 \pm 10$ \\
Body mass $(\mathrm{kg})$ & $64.6 \pm 12.0$ \\
Height $(\mathrm{m})$ & $1.54 \pm 0.07$ \\
Body mass index $\left(\mathrm{kg} / \mathrm{m}^{2}\right)$ & $27.1 \pm 3.8$ \\
Ankle-brachial index & $0.66 \pm 0.15$ \\
Cardiovascular risk factors (\%) & \\
Hypertension & 84.2 \\
Diabetes mellitus & 36.8 \\
Current smoking & 26.3 \\
Obesity & 21.1 \\
Dyslipidemia & 36.8 \\
Medications (\%) & \\
Angiotensin-converting enzyme inhibitor & 42.1 \\
Angiotensin Il receptor antagonist & 31.6 \\
Calcium channel blocker & 31.6 \\
Diuretics & 47.4 \\
Beta blocker & 10.5 \\
\hline
\end{tabular}


Figure 2 illustrates the responses of HR and RPP during the resistance exercise.

Significant increases compared to pre-exercise values were observed for HR (pre-exercise $=$ $76 \pm 18$ bpm vs. peak $=104 \pm 30$ bpm; $\Delta=+30 \pm$ 28 bpm; $<<0.001$ ) and RPP (pre-exercise $=9523 \pm$ $2115 \mathrm{bpm} \times \mathrm{mmHg}$ vs. peak $=19103 \pm 6098 \mathrm{bpm} \mathrm{x}$ $\mathrm{mmHg} ; \Delta=+9845 \pm 5912$ bpm x mmHg; $\mathrm{p}<0.001)$.
Figure 3 illustrates the relationship between relative $\Delta$ of SBP and SBP at rest (Figure $3 \mathrm{~A}$ ) and between relative $\Delta$ of SBP and ABI (Figure 3B).

A negative and significant relationship was observed between relative $\triangle$ of SBP and SBP at rest $(r=-0.549 ; p=0.022)$. On the other hand, no relationship was observed between relative $\triangle$ of SBP and $\mathrm{ABI}(\mathrm{r}=0.076 ; \mathrm{p}=0.771)$.
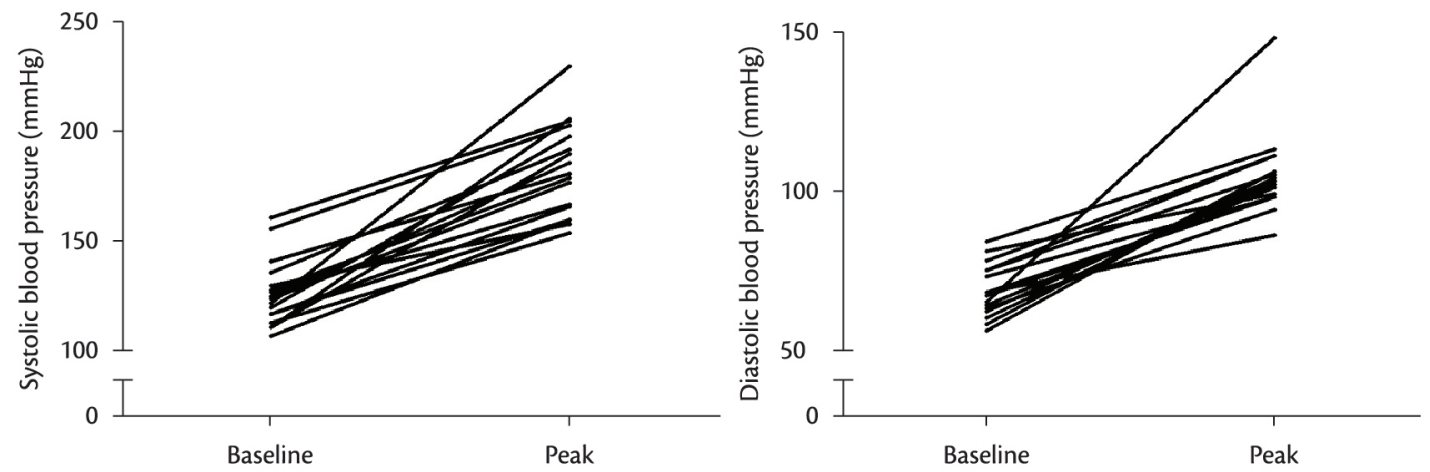

Figure 1. Responses of systolic and diastolic arterial blood pressure during resistance exercise.
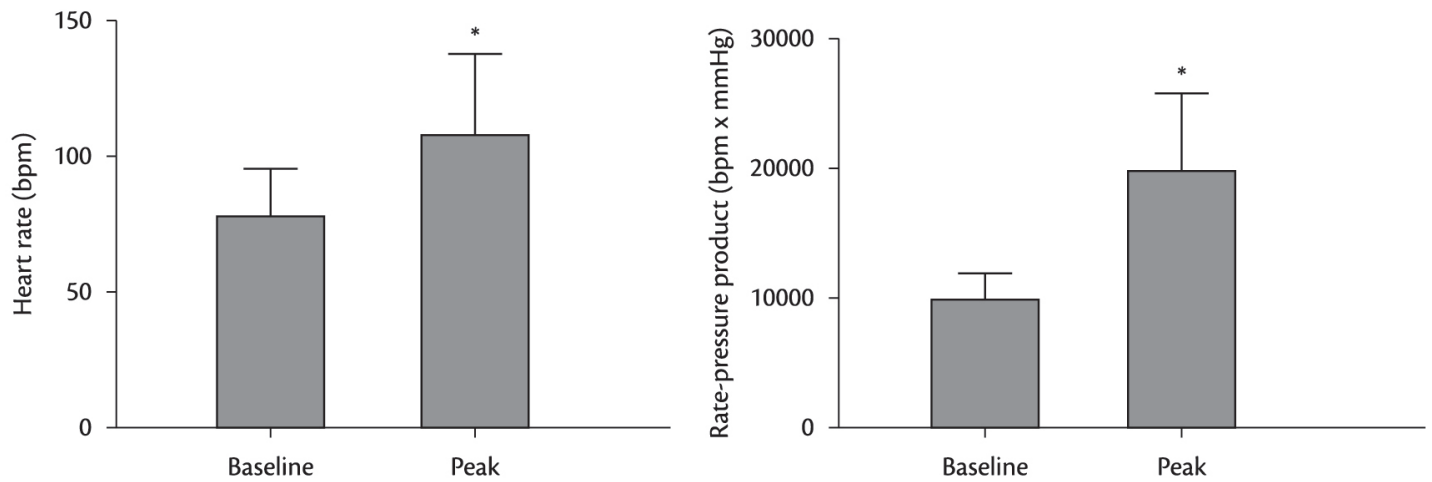

Figure 2. Responses of heart rate and rate-pressure product during resistance exercise. *Significant difference compared to preexercise baseline $(p<0.001)$.
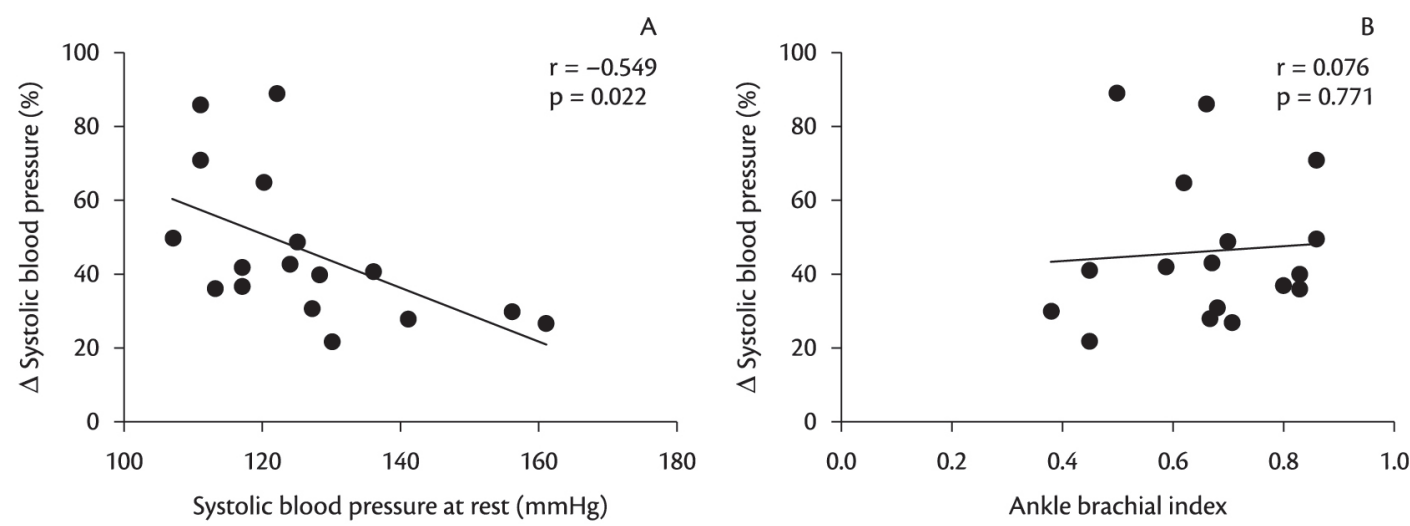

Figure 3. Relationship between relative $\Delta$ of systolic arterial blood pressure and baseline systolic arterial blood pressure at rest (panel A) and the ankle-brachial index (panel B). 


\section{DISCUSSION}

The objective of this study was to analyze cardiovascular responses during resistance exercise in patients with PAD, in addition to verifying the correlation between cardiovascular responses and disease severity and resting SBP. To date, this is the first study to describe cardiovascular responses during isoinertial resistance exercise in patients with PAD. The results demonstrated an accentuated increase in SBP, DBP, HR and RPP during resistance exercise and show that these changes are not related to disease severity. Additionally, the responses of arterial blood pressure measurements to resistance exercise were inversely proportional to the results for arterial blood pressure at rest.

Souza Nery et al. ${ }^{13}$ analyzed the responses of SBP and DBP during the knee extension exercise in ten hypertense patients without anti-hypertensive medication and found higher peak values than were observed in the present study (SBP $-238 \pm 12 \mathrm{mmHg}$ vs. $184 \pm 20 \mathrm{mmHg}$; DBP $-140 \pm 8 \mathrm{mmHg}$ vs. $104 \pm$ $14 \mathrm{mmHg}$ ). These results can be partially explained by the fact that the PAD patients were taking antihypertensive medications, as part of their routine clinical care and in view of their additional associated comorbidities. ${ }^{22}$ Indeed, $89 \%$ of the patients in the present study were taking anti-hypertensive medications, which possibly attenuated the increases in SBP and DBP during resistance exercises. ${ }^{23,24}$ Another factor that can also explain the smaller increases in SBP and DBP in the present study is the sub-maximal resistance exercise protocol employed, in contrast with the study mentioned above in which subjects exercised to exhaustion, which is known to accentuate arterial blood pressure responses to resistance exercise. ${ }^{13}$

The results of this study include the finding that five patients exhibited SBP values over $200 \mathrm{mmHg}$, and one patient exhibited a maximum SBP of $230 \mathrm{mmHg}$. These values are lower than results reported by Bakke et al., ${ }^{25}$ who observed SBP values exceeding $300 \mathrm{mmHg}$ in patients with PAD while they walked on a treadmill and which has been attributed to activation of the pressor reflex, in view of the lower limb ischemia. ${ }^{26}$ Along the same lines, Cucato et al. ${ }^{27}$ also observed values for SBP exceeding $230 \mathrm{mmHg}$. In practical terms, these findings suggest that the cardiovascular responses of PAD patients during the type of exercise analyzed here are comparable to or of lower magnitude than the responses that have been observed to exercising on a treadmill, providing evidence in favor of the safety of resistance exercise for these patients.

The results of the present study do not provide evidence of a significant correlation between increases in SBP during resistance exercises and the patients' ABI. This result reinforces the findings of an earlier study, ${ }^{28}$ which also failed to detect any association between cardiovascular variables and ABI, arterial elasticity or reactive hyperemia during a test in which the exercise modality was walking with a constant load. As such, even though $\mathrm{ABI}$ is considered a predictor of cardiovascular risk and mortality in these patients, ${ }^{29}$ it is not related to the magnitude of cardiovascular responses during exercise in these patients. Notwithstanding, in this study a negative and significant correlation was observed between resting SBP and change in SBP during resistance exercise, suggesting that the higher the SBP at rest, the smaller the increase during resistance exercise. One explanation for this result is that the anti-hypertensive medications may have attenuated SBP response in patients with higher pre-exercise pressure. ${ }^{24,25}$

Certain factors limiting interpretation of the results of the present study should be mentioned. There was no disease-free group, which would have made it possible to identify the specific effect of PAD on cardiovascular responses. This was the result of the difficulty of enrolling individuals with similar age and clinical characteristics (comorbidities and medication usage) to the patients with PAD. Another limitation is that just one set of sub maximal resistance exercise was conducted, ruling out the possibility of analyzing the effects of exercise to exhaustion on cardiovascular responses. Additionally, only one exercise intensity was analyzed, limiting extrapolation of the results to other intensities. Finally, only one resistance exercise was tested, ruling out analysis of cardiovascular behavior during other exercises.

In conclusion, the results of this study showed that resistance exercise increased cardiovascular variables in patients with $\mathrm{PAD}$ and that these changes were not related to disease severity. Additionally, SBP responses to resistance exercise were inversely proportional to blood pressure values at rest. As future avenues for research, we suggest assessment of cardiovascular responses in individuals taking lower quantities of medications and assessment of cardiovascular responses during different types of resistance exercise, thereby providing more in-depth knowledge of cardiovascular responses during this type of exercise in patients with PAD. 


\section{ACKNOWLEDGEMENTS}

The authors are grateful to the following research funding agencies: the Fundação de Amparo à Ciência e Tecnologia do Estado de Pernambuco (FACEPE), the Conselho Nacional de Desenvolvimento Científico e Tecnológico (CNPq) and the Coordenação de Aperfeiçoamento de Pessoal de Nível Superior (CAPES).

\section{REFERENCES}

1. Norgren L, Hiatt WR, Dormandy JA, Nehler MR, Harris KA, Fowkes FG, et al. Inter-society consensus for the management of peripheral arterial disease. Int Angiol. 2007;26(2):81-157. PMid:17489079.

2. Makdisse M, Pereira AC, Brasil DP, Borges JL, Machado-Coelho $\mathrm{GL}$, Krieger JE, et al. Prevalence and risk factors associated with peripheral arterial disease in the Hearts of Brazil Project. Arq Bras Cardiol. 2008;91(6):370-82. PMid:19142364.

3. Meves SH, Diehm C, Berger K, Pittrow D, Trampisch HJ, Burghaus I, et al. Peripheral arterial disease as an independent predictor for excess stroke morbidity and mortality in primary-care patients: 5-year results of the getABI study. Cerebrovasc Dis. 2010;29(6):54654. http://dx.doi.org/10.1159/000306640. PMid:20375496

4. Caro J, Migliaccio-Walle K, Ishak KJ, Proskorovsky I. The morbidity and mortality following a diagnosis of peripheral arterial disease: long-term follow-up of a large database. BMC Cardiovasc Disord. 2005;5(1):14-21. http://dx.doi.org/10.1186/1471-2261-5-14. PMid:15972099

5. Diehm C, Schuster A, Allenberg JR, Darius H, Haberl R, Lange $S$, et al. High prevalence of peripheral arterial disease and comorbidity in 6880 primary care patients: cross-sectional study. Atherosclerosis. 2004;172(1):95-105. http://dx.doi.org/10.1016/ S0021-9150(03)00204-1. PMid:14709362

6. Wolosker N, Rosoky RA, Nakano L, Basyches M, Puech-Leão P. Predictive value of the ankle-brachial index in the evaluation of intermittent claudication. Rev Hosp Clin Fac Med Sao Paulo. 2000;55(2):61-4. http://dx.doi.org/10.1590/S004187812000000200005. PMid:10959125

7. Topakian R, Nanz S, Rohrbacher B, Koppensteiner R, Aichner FT, and the OECROSS Study Group. High prevalence of peripheral arterial disease in patients with acute ischaemic stroke. Cerebrovasc Dis. 2010;29(3):248-54. http://dx.doi. org/10.1159/000267850. PMid:20029198

8. Hirsch AT, Haskal ZJ, Hertzer NR, Bakal CW, Creager MA, Halperin $\mathrm{JL}$, et al. Practice Guidelines for the management of patients with peripheral arterial disease (lower extremity, renal, mesenteric, and abdominal aortic): a collaborative report from the American Association for Vascular Surgery/Society for Vascular Sur. Circulation. 2005;113(11):463-654.

9. Ritti-Dias RM, Wolosker N, Moraes Forjaz CL, Carvalho CR, Cucato $\mathrm{GG}$, Leão PP, et al. Strength training increases walking tolerance in intermittent claudication patients: randomized trial. J Vasc Surg. 2010;51(1):89-95. http://dx.doi.org/10.1016/j.jvs.2009.07.118. PMid:19837534

10. McDermott MM, Ades P, Guralnik JM, Dyer A, Ferrucci L, Liu K, et al. Treadmill exercise and resistance training in patients with peripheral arterial disease with and without intermittent claudication: a randomized controlled trial. JAMA.
2009;301(2):165-74. http://dx.doi.org/10.1001/jama.2008.962. PMid:19141764

11. Cucato GG, Ritti-Dias RM, Wolosker N, Santarém JM, Jacob Filho W, Forjaz CLMF. Post-resistance exercise hypotension in patients with intermittent claudication. Clinics (Sao Paulo). 2011;66(2):221-6. http://dx.doi.org/10.1590/S1807. 59322011000200007. PMid:21484037

12. MacDougall JD, Tuxen D, Sale DG, Moroz JR, Sutton JR. Arterial blood pressure response to heavy resistance exercise. J App Physiol (1985). 1985;58(3):785-90. PMid:3980383.

13. Souza Nery SS, Gomides RS, Silva GV, Moraes Forjaz CL, Mion D $J r$, Tinucci T. Intra-arterial blood pressure response in hypertensive subjects during low- and high-intensity resistance exercise. Clinics (Sao Paulo). 2010;65(3):271-7. http://dx.doi.org/10.1590/S1807 59322010000300006. PMid:20360917

14. Bennett T, Wilcox RG, Macdonald IA. Post-exercise reduction of blood pressure in hypertensive men is not due to acute impairment of baroreflex function. Clin Sci. 1984;67(1):97-103. PMid:6734082.

15. Fleck SJ, Dean LS. Resistance-training experience and the pressor response during resistance exercise. J Appl Physiol (1985) 1987;63(1):116-20. PMid:3624118.

16. Câmara LC, Ritti-Dias RM, Forjaz CL, Greve JM, Santarém JM Jacob-Filho W, et al. Cardiovascular responses during isokinetic muscle assessment in claudicant patients. Arq Bras Cardiol. 2010;95(5):571-6. PMid:21109918.

17. Gomides RS, Dias RM, Souza DR, Costa LA, Ortega KC, Mion D, et al. Finger blood pressure during leg resistance exercise. Int J Sports Med. 2010;31(8):590-5. http://dx.doi org/10.1055/s-0030-1252054. PMid:20432200

18. Clarke DH. Adaptations in strength and muscular endurance resulting from exercise. Exerc Sport Sci Rev. 1973;1(1):73 102. http://dx.doi.org/10.1249/00003677-197300010-00007. PMid:4806385

19. Chagas, MH, Barbosa, JRM, Lima, FV. Comparação do número máximo de repetições realizadas a $40 \%$ e $80 \%$ de uma repetição máxima em dois diferentes exercícios na musculação entre os gêneros masculino e feminino. Rev Bras Educ Fís Esp. 2005;19:5-12.

20. Câmara LC, Santarém JM, Wolosker N, Dias RMR. Exercícios resistidos terapêuticos para indivíduos com doença arterial obstrutiva periférica: evidências para a prescrição. J Vasc Bras. 2007;6(3):246-56. http://dx.doi.org/10.1590/ S1677-54492007000300008.

21. Bos WJ, Imholz BP, van Goudoever J, Wesseling KH, van Montfrans $\mathrm{GA}$. The reliability of noninvasive continuous finger blood pressure measurement in patients with both hypertension and vascular disease. Am J Hypertens. 1992;5(8):529-35. PMid:1388963.

22. Olin JW, Sealove BA. Peripheral artery disease: current insight into the disease and its diagnosis and management. Mayo Clin Proc. 2010;85(7):678-92. http://dx.doi.org/10.4065/mcp.2010.0133. PMid:20592174

23. Gomides RS, Costa LA, Souza DR, Queiroz AC, Fernandes $J R$, Ortega KC, et al. Atenolol blunts blood pressure increase during dynamic resistance exercise in hypertensives. $\mathrm{Br}$ J Clin Pharmacol. 2010;70(5):664-73. http://dx.doi.org/10.1111/j.1365 2125.2010.03742.x. PMid:21039760

24. Moraes MF, Alexandre GL, Borges PG, Diego Leite R, Vieira A, Frade de Sousa NM, et al. Different cardiovascular responses to a resistance training session in hypertensive women receiving propanolol compared with normotensive controls. ScientificWorldJournal. 2012;2012:913271. 
25. Bakke EF, Hisdal J, Jørgensen JJ, Kroese A, Stranden E. Blood pressure in patients with intermittent claudication increases continuously during walking. Eur J Vasc Endovasc Surg. 2007;33(1):20-5. http://dx.doi.org/10.1016/j.ejvs.2006.06.023. PMid:16934498

26. Baccelli G, Reggiani P, Mattioli A, Corbellini E, Garducci S, Catalano $M$. The exercise pressor reflex and changes in radial arterial pressure and heart rate during walking in patients with arteriosclerosis obliterans. Angiology. 1999;50(5):361-74. http:// dx.doi.org/10.1177/000331979905000502. PMid:10348424

27. Cucato GG, Rodrigues LBCC, Farah BQ, Lins OL, Rodrigues SLC, Forjaz CLM, et al. Cardiovascular responses to an exercise test in subjects with intermittent claudication. Rev Bras Cineantropom Desempenho Hum. 2011;13:208-15.

28. Ritti-Dias RM, Meneses AL, Parker DE, Montgomery PS, Khurana A, Gardner AW. Cardiovascular responses to walking in patients with peripheral artery disease. Med Sci Sports Exerc. 2011;43(11):2017-23. http://dx.doi.org/10.1249/ MSS.0b013e31821ecf61. PMid:21502888

29. Sheikh MA, Bhatt DL, Li J, Lin S, Bartholomew JR. Usefulness of postexercise ankle-brachial index to predict all-cause mortality. Am J Cardiol. 2011;107(5):778-82. http://dx.doi.org/10.1016/j. amjcard.2010.10.060. PMid:21247542
Correspondence

Raphael Mendes Ritti Dias

Escola Superior de Educação Física, ESEF/UPE

Rua Arnóbio Marques, 310, Santo Amaro, Campus Universitário

HUOC - ESEF

CEP 50100-130 - Recife (PE), Brazil

Tel.: +55 (81) 3183-3379

E-mail: raphael.ritti@upe.br

Author information

APFG is an MSc in Physical Education from the Associate Graduate Program in Physical Education at UPE/UFPB.

TMPP holds a bachelor's degree in Physical Education from

Universidade de Pernambuco (UPE) and is an MSc candidate in

Physical Education at the Associate Graduate Program in Physical Education at UPE/UFPB

MAC is an MSc in Physical Education and a PhD candidate in Physica Education at the Associate Graduate Program in Physical Education at UPE/UFPB

FSS holds a bachelor's degree in Physical Education from Universidade de Pernambuco (UPE) and is an MSc candidate in Adolescent Medicine at UPE.

BQF is an MSc in Adolescent Medicine from Universidade de Pernambuco (UPE) and a PhD candidate in Physical Education at the Associate Graduate Program in Physical Education at UPE/UFPB. RMR is a PhD in Public Health from Universidade de São Paulo (USP) and a professor at the Associate Graduate Program in Physical Education at UPE/UFPB

Author contributions Conception and design: RMR, APFC Analysis and interpretation: APFG, BQF, RMR

Data collection: TMPP, MAC, FSS Writing the article: APFG, TMPP, RMR Critical revision of the article: $M A C, B Q F$, FSS Final approval of the article*: APFG, TMPP, MAC, FSS, BQF, RMR Statistical analysis: BQF, APFC Overall responsibility: RMR

*All authors have read and approved of the final version of the article submitted to J Vasc Bras. 